\title{
Cytomorphology of six halotolerant coccoid cyanobacteria using DAPI fluorescent and transmission electron microscopy, compared with molecular data
}

\author{
Vladislav CEPÁK* \& Jiř́i KOMÁREK
}

Academy of Sciences of the Czech Republic, Institute of Botany v.v.i., Centre for Algology, Dukelská 135, CZ-379 82 Třebon̆,Czech Republic; *e-mail: cepak@botany.cas.cz

\begin{abstract}
Cytomorphological characters of six strains of unicellular cyanophytes, all belonging to "Euhalothece/ Halothece" group in the sense of GARCIA-PICHEL et al. (1998), but of different hypersaline origin, have been studied using DAPI fluorescent staining and light and transmission electron microscopy. They can be divided into two clades, which are well separated according to phenotypic taxonomy (morphology, cytology and ultrastructure). The first group (four strains) could be included in the subcluster "Euhalothece" (on the generic level, but not yet validly described). Broad oval cells of ca 4-6 $\mu \mathrm{m}$ breadth with indistinct chromatoplasm, net like nucleoids and parallel lengthwise-arranged thylakoids often in fascicles are characteristic for this group. The second subcluster should be classified into another genus because of oblong or rod-shaped cells of smaller size (cca 2-4 $\mu \mathrm{m}$ wide), peripheral "chromatoplasm" (position of mostly lengthwise parietal thylakoids) and more or less compact nucleoid. These strains belong into the vicinity of the genus Cyanobium.
\end{abstract}

Key words: Cyanobacteria, Cyanobium, Cyanothece, DAPI staining, Halothece, Euhalothece, nucleoid, taxonomy, TEM

\section{Introduction}

Contemporary cyanobacterial taxonomy often follows combination of two methodological approaches. The "classical" method, based on visible characters (morphological, cytological, physiological and ultrastructural) together with ecology should be combined with increasingly employed modern molecular methods, e.g. DNA base composition (HeRdMAn et al. 1979), DNA/DNA hybridisation (STAM \& STULP 1988), sequence-specific deoxyribonucleases (WAARD \& Duyvesteyn 1980), nucleotide sequence of the 16S rRNA (WiLmotte et al. 1992) and amplified rDNA restriction analysis (GARCIA-PICHEL et al. 1998). However, most studies utilize only one approach for two reasons. First, many researchers lack certain phylogenetically important strains. Second, information relating to original or natural materials is often difficult or impossible to obtain. Further, molecular data are not always in agreement with classical botanical characterization and the synthesis of such results is difficult in some cases.
GARCIA-Pichel and colleagues studied 13 strains of extremely halotolerant coccoid cyanobacteria on the basis of $16 \mathrm{~S}$ rRNA gene sequences (GARCIA-PicheL et al. 1998). They separated the "Halothece" subcluster (represented by only one strain originating from Mexico), which was later validated as a genus by MARGHERI et al. (2008), due to a complex evaluation of genetics, morphology, ecophysiology and ultrastructure. The second subcluster "Euhalothece" contains 12 strains, which were all more than $95 \%$ similar in 16S rRNA gene sequence one to another, but they were not yet validly described on the generic level. MARGHERI et al. (1999) assessed genetic diversity of a set of novel 12 strains (using amplified 16S rDNA restriction analysis), and after comparison with the dendrogram depicted by GARCiA-PicheL et al. (1998) they concluded that these strains belong also to Euhalothece subcluster (cf. Fig. 13).

The aim of our study is to provide phenotypic characterisation and diversity of some strains studied by MARGHERI et al. (1999) and compare them with the genetic diversity represented by $16 \mathrm{~S}$ 
rRNA gene sequence analysis. We conclude that results obtained by both approaches are congruent (the botanical approach is in agreement with the genetic one).

\section{Materials and methods}

Organisms and culture conditions. The strains CE 9 , TP 5, 16Som 2, CA 3, VI 22, and PE 14 were obtained from Dr. M.C. Margheri and their origin is listed elsewhere (MARGHERI et al. 1999). All of the strains originated from hypersaline environments. The cultures were grown in test tubes $(10 \mathrm{ml})$ in liquid medium (commercial seawater salts -33.33 g. $1^{-1}, \mathrm{~K}_{2} \mathrm{HPO}_{4} .3 \mathrm{H}_{2} 0$ -0.04 g. $1^{-1}, \mathrm{NaHCO}_{3}-0.1$ g. $1^{-1}$, citric acid $-0.003 \mathrm{~g} . \mathrm{l}^{-1}$, ferric ammonium citrate - 0.003 g..$^{-1}$, EDTA sodium salt -0.0005 g. $1^{-1}$, trace elements of BG-11 medium $-0.5 \mathrm{ml}$ per litre). Cultures were slightly aerated, temperature maintained at $30^{\circ} \mathrm{C}$ and continuous white light adjusted to about $50 \mu \mathrm{mol} \mathrm{m}{ }^{2} . \mathrm{s}^{-1}$.

DAPI staining and fluorescence microscopy. Month-old cells were centrifuged, the resulting pellet resuspended in Tris buffer ( $\mathrm{pH}=7.2)$, and cells fixed in $1 \%$ glutaraldehyde at $20^{\circ} \mathrm{C}$ for $30 \mathrm{~min}$. DNA was stained with DAPI $\left(1 \mu \mathrm{g} \mathrm{ml}^{-1}\right.$ in Tris buffer $)$ as described earlier (СЕРÁK 1996a). The preparations were examined with an epifluorescence microscope (OLYMPUS BX 60, Japan) connected to a COHU High Performance LLD.

Transmission electron microscopy. Samples preserved with $2 \%$ of formaldehyde were washed, postfixed with glutaraldehyde in cacodylate buffer and stained with $\mathrm{OsO}_{4}$. After dehydration in an acetone series the samples were embedded in Spur resin, cut, and then investigated in a transmission electron microscope (Jeol JEM 1010, Japan).

\section{Results and discussion}

We examined six strains of extremely halotolerant coccoid cyanobacteria isolated from hypersaline environments (MARGHERI et al. 1999). Using traditional taxonomic approaches, we report in more detail the cytomorphology of nucleoids using DAPI fluorescence staining and thylakoid patterns employing transmission electron microscopy. Our results were compared with the most closely related genera Cyanobium, Cyanobacterium, Halothece and Cyanothece (Table 1). We conclude that the strains examined can be divided into two groups, which are well separated with their cytomorphological and ultrastructural characters (I and II in Table 1).

The first group contains a uniform type of cells which are broadly oval-shaped and 4-6 $\mu \mathrm{m}$ in size (Figs 1-4). The size and outer shape of nucleoids coincide well with the dimensions and shape of the cells. DNA is concentrated into small skeins of various shape-oval, elongated or globular, which are connected by thin filaments of DNA. In the fluorescent microscope indistinct or narrow peripheral layer was observed. Nucleoids similar in appearance were observed previously in Cyanothece aeruginosa (СЕРÁK 1993, 1996a) and Cyanothece halobia (СЕРÁK 1996a). Contrary to the strains above, which contain parallel and lengthwise-arranged thylakoids (indistinct fascicles) spread throughout the whole cell (Figs 7-10), the type species Cyanothece aeruginosa (KomÁreK 1976, KomÁreK et al. 2004) is distinguished by radially-arranged fascicles of thylakoids, small intrathylakoidal spaces, and distinctly larger dimensions. In addition, they differ in ecology, as C. aeruginosa was isolated from acidic marshes. For this reason the strains studied were compared with the halophilic strain $\mathrm{CH} 1$, designated as C. halobia (MARGHERI et al. 1999), which should be separated also from the genus Cyanothece and shifted into another genus. Cyanothece halobia (strain CH1) was studied previously by RousSOMOUSTAKAKI \& ANAGNOSTIDIS (1991), СЕРÁK (1996a) and KoMÁreK et al. (2004). According to Garcia-Pichel et al. (1998) and MARGHERI et al. (1999), the cluster of "Euhalothece", to which belong also the studied strain (Table 1, group 1) seems to be suitable genus different from Cyanothece in the original sense for such cyanobacteria, but has not yet been validly described and published. "Euhalothece" and "Cyanothece sensu Rippka" contain more then 30 strains deposited in various collections and need further studies. The validation of these genera under the Botanical Code, containing these strains (it concerns also the related strain PCC 8305 of "Dactylococcopsis salina") is expected, but needs further data and therefore will be solved in the next study.

The second group of strains posesses smaller-sized cells, which are oblong or rodshaped and about 2-3(4) $\mu \mathrm{m}$ long. In contrast to the first group, we have observed more compact nucleoids with big skeins of DNA without visible DNA threads (Figs 5,6). A distinct layer of "chromatoplasm" was visible and parietal thylakoids concentrated along the cell walls are typical for these strains (Figs 11,12). Both strains fit the description of the Cyanobium type according to cell size and shape and nucleoid morphology 


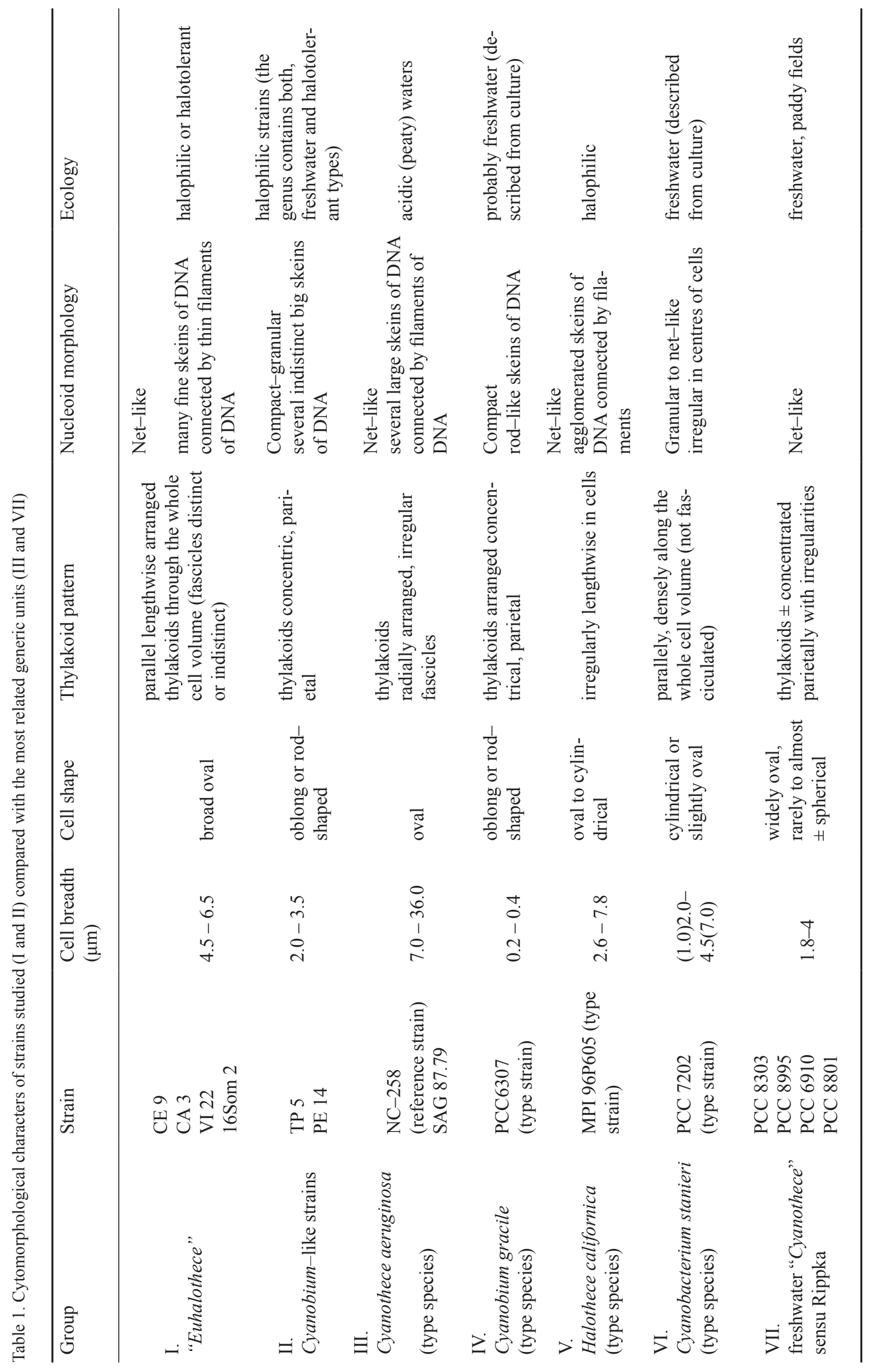



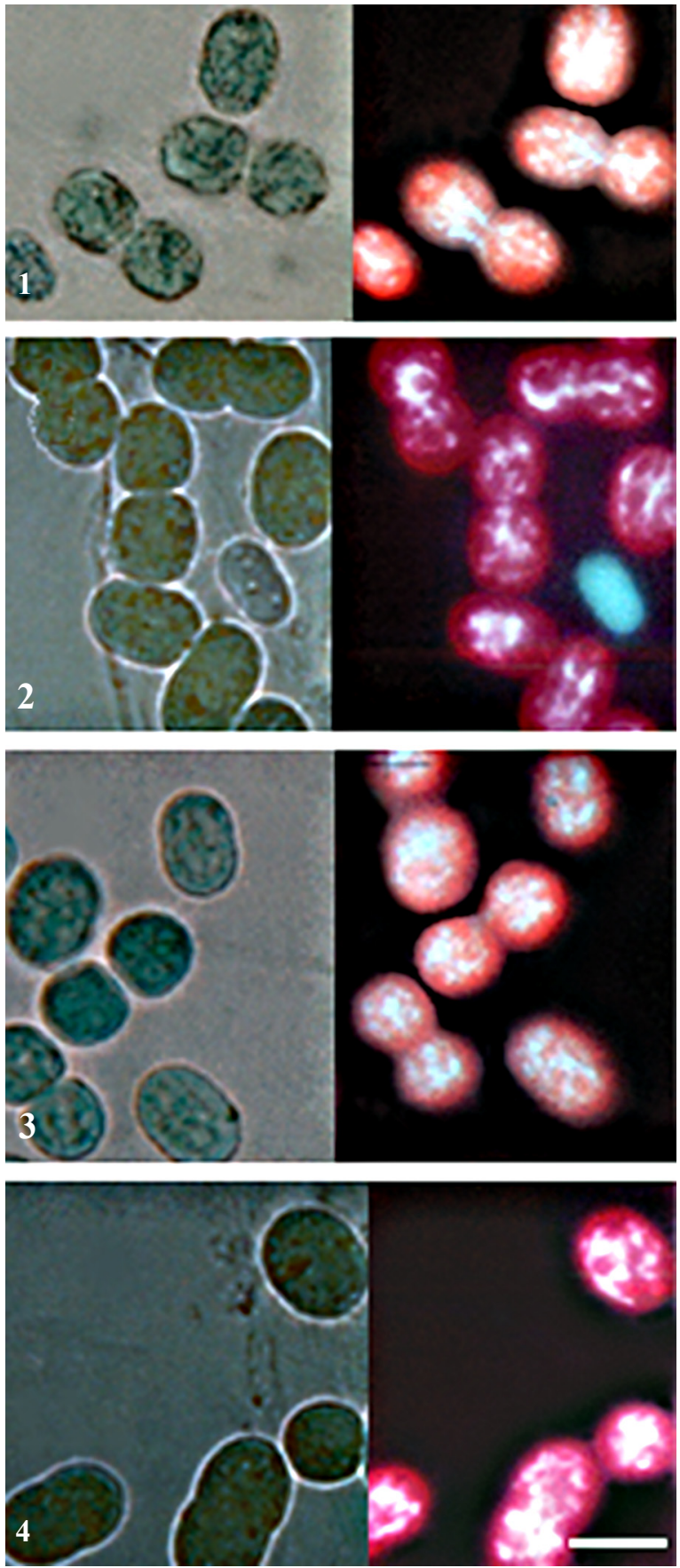

Figs 1-4. Cells under the light microscope (left row) and the same DAPI fluorescent micrographs of "Euhalothece" strains (right row). Cells are large broad oval with net-like nucleoids: (1) CE 9; (2) VI 22; (3) 16Som 2; (4) CA 3. Scale bar $5 \mu \mathrm{m}$.

(KoMÁReK et al. 1999). Thylakoids are arranged lengthwise and mostly concentrically (parietal arrangement).

Summary: "Halothece/Euhalothece" cluster sensu lato was defined by GARCIA-PICHEL et al. (1998) on the basis of 16S rRNA gene sequence analysis as a group of extremely halotolerant
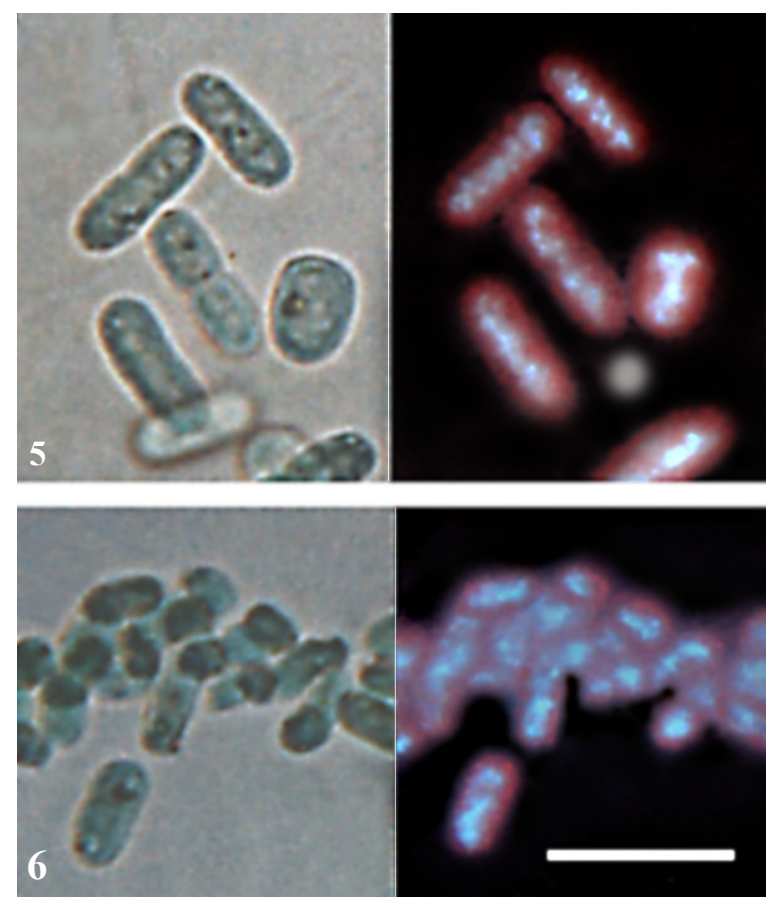

Figs 5, 6. Cells under the light microscope (left row) and the same DAPI fluorescent micrographs of Cyanobium-like strains (right row). Strains are smaller with oblong or rodshaped cells and granular, more or less compact nucleoids: (5) TP5; (6) PE 14. Scale bar $10 \mu \mathrm{m}$.

cyanobacteria (sustained growth in the range $6-16 \%$ salinity). However this monophyletic cluster includes strains belonging to different genera according to the traditional botanical system as well as molecular evaluation (deviations in the phylogenetic tree). The designation of "Halothece" as a separate cluster was restricted to one strain MPI 96P605 (CASTENHolz 1969, Margheri et al. 1999, Turner et al. 2001, KomÁreK et al. 2004); its generic status and relations to "Euhalothece" were confirmed by MARGHERI et al. (2008).

Other "Euhalothece" strains and mostly halophilic "Cyanothece" strains sensu RIPPKA \& COHEN-BAZIRE (1983) evidently also belong into few separated clusters. They are similarparticularly with respect to main cell morphology (solitary oval cells) and nucleoid division. The cells divide only by binary fission (pinching), they do not form any chains (in contradiction to Halothece under special conditions in cultures) and newly formed daughter cells are alike. Nucleoid division is obviously passive because it occurred simultaneously with cell fission. This cluster is evidently different from typical Cyanothece, which is based on the species $C$. aeruginosa. According to our results, the generic status of "Euhalothece", to which our strains CE9, CA3, VI 22 and 16Som 2 belong, is 

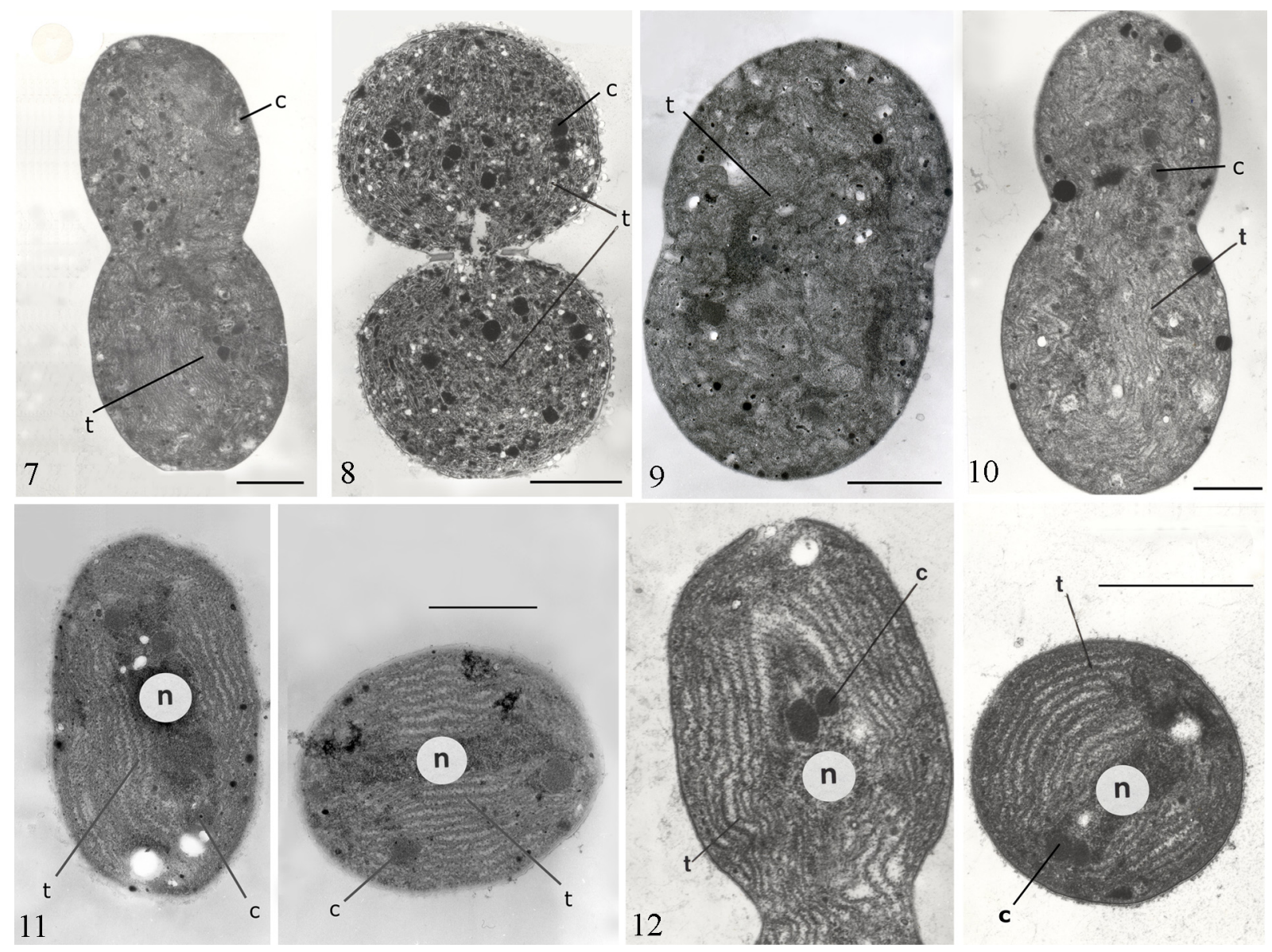

Figs 7-10. Longitudinal section of cells of "Euhalothece"-like strains: (7) CE 9; (8) VI 22; (9) 16Som 2; (10) CA 3. Thylakoids are mostly longitudinally and irregularly spread throughout the whole cell volume, often in fascicles. Scale bar $1 \mu \mathrm{m}$.

Figs 11, 12. Lengthwise- (a) and cross-sections (b) of cyanobacterial cells of Cyanobium-like strains: (11) PE 14; (12) TP5. Thylakoids (t) are lengthwise oriented, parietally and concentric; (n) ,nucleoplasm“, (c) carboxysomes. Scale bar $1 \mu \mathrm{m}$.

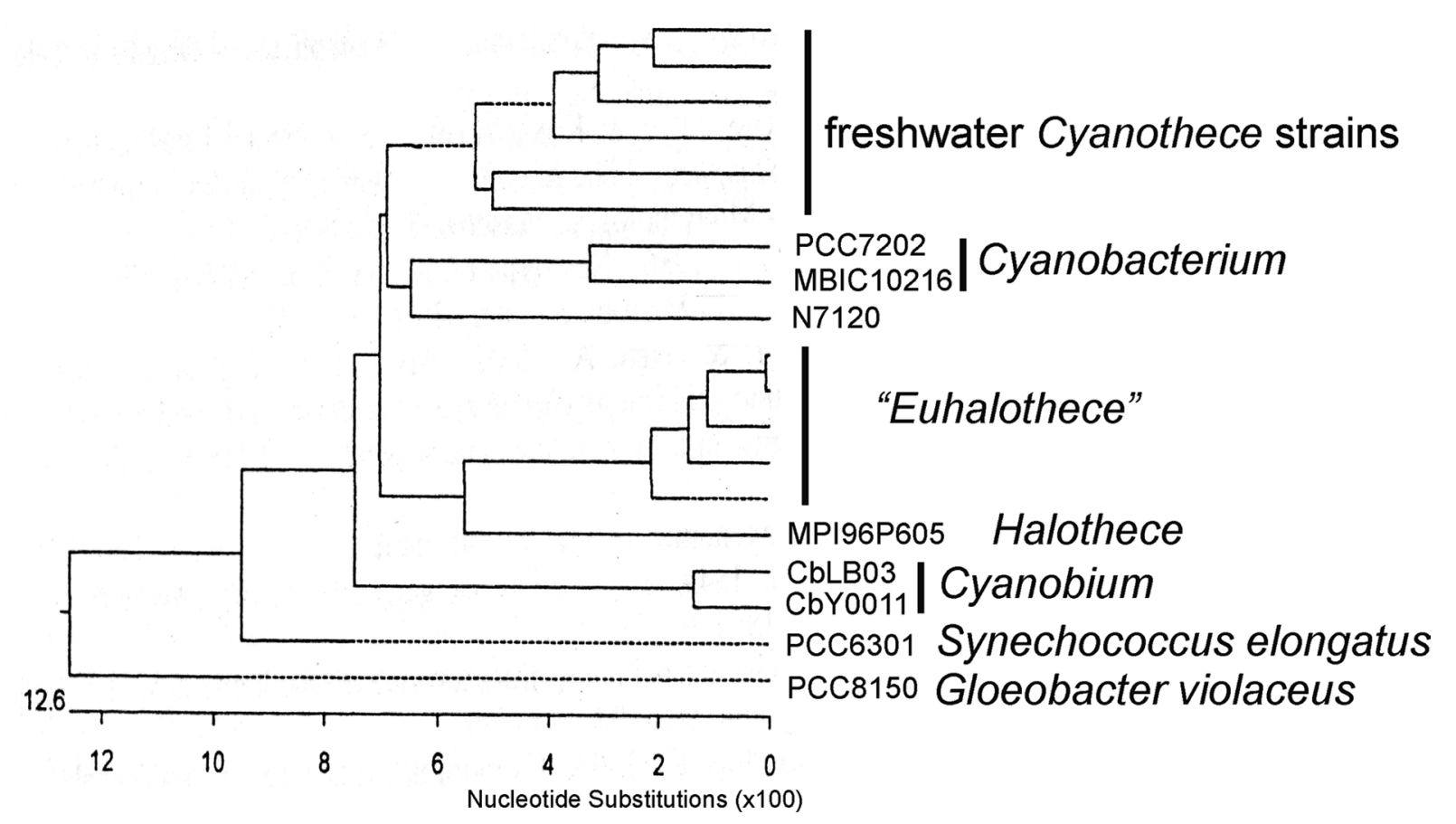

Fig 13. The phylogenetic tree derived from Megalign (DNA Star) from GenBank of NCBI, illustrating the clusters on the generic level ("Euhalothece", Halothece, Cyanobium and Cyanobacterium strains). Partly derived from MArgHerI et al. (1999). 
confirmed and should be classified as a special halophilic genus. Our studies also confirmed that the strain CH1 (Cyanothece halobia) belongs to this generic unit.

Two our other strains (TP5, PE14) belong in the genus Cyanobium RIPPKA et COHEN-BAZIRE 1983, and are mostly related to the halophilic species Cyanobium bacillare, which was, however, described only according the morphological characters (KomÁREK \& ANAGNOSTIDIS 1998). Our strains of "Euhalothece" and Cyanobium belong into the separate clusters, which are illustrated in Fig. 13 (cf. dendrogram in MARGHERI et al. 1999, Fig. 3). Little problematic is only the strain TP5. Their respective specific definition should be studied in future.

\section{Acknowledgements}

We are indebted to the reviewer for English corrections and all remarks to the manuscript. This work was supported by the institutional long-term research plan no AV0Z60050516 funded by the Academy of Sciences of the Czech Republic and GA AS CR no IAA600050704.

\section{References}

Castenholz, R.W. (1969): Thermophilic blue-green algae and the thermal environment. - Bacteriol. Rev. 33: 476-504.

CEPÁK, V. (1993): Morphology of DNA containing structures (nucleoids) as a prospective character in Cyanophyte taxonomy. - J. Phycol. 29: 844-852.

CEPÁK, V. (1996a): Nucleoid morphology in the coccal cyanophyte Cyanothece halobia (Chroococcales, Cyanophyta) - a DAPI fluorescence study. Phycologia 35: 523-527.

CepÁk, V. (1996b): Variability of nucleoid morphology of some cyanophytes growing under various growth conditions. - Algological Studies 81: 39-52.

Garcia-Pichel, F., Nübel, U. \& Muyzer, G. (1998): The phylogeny of unicellular, extremely halotolerant cyanobacteria. - Arch. Microbiol. 169: 469-482.

Herdman, M., Janvier, M., Waterbury, J.B., Rippka, R. \& Stanier, R.Y. (1979): Deoxyribonucleic acid base composition of cyanobacteria. - J. Gen. Microbiol. 111: $63-71$.

KomÁreK, J. (1976): Taxonomic review of the genera Synechocystis SAUV. 1892, Synechococcus NÄG.1849, and Cyanothece gen. nov. (Cyanophyceae). - Arch. Protistenk. 118: 119-179.

KomÁreK, J. \& Anagnistidis, K. (1999): Cyanoprokaryota 1.Teil: Chroococcales. - In: Ettl, H., Gärtner, G., Heynig, H. \& Mollenhauer, D. (eds): Süsswasserflora von Mitteleuropa 19/1. - 548 pp., Gustav Fischer, Jena-Stuttgart-Lübeck-Ulm.

KomÁrek, J. \& CepÁK, V. (1998): Cytomorphological characters supporting the taxonomic validity of
Cyanothece (Cyanoprokaryota). - Plant. Syst. Evol. 210: 25-39.

Komárek, J., Cepák, V., KaštovskÝ, J. \& Sulek, J. (2004): What are the cyanobacterial genera Cyanothece and Cyanobacterium? Contribution to the combined molecular and phenotype taxonomic evaluation of cyanobacterial diversity. -Algological Studies 113: $1-36$.

KomÁrek, J., KopeckÝ, J. \& CерÁK, V. (1999): Generic characters of the simplest Cyanoprokaryota Cyanobium, Cyanobacterium and Synechococcus. Cryptogamie Algologie 20: 209-222.

Margheri, M.C., Bosco, M., Giovannetti, L. \& Ventura, S. (1999): Assessment of the genetic diversity of halotolerant coccoid cyanobacteria using amplified 16S rDNA restriction analysis. FEMS. - Microbiol. Lett. 173: 9-16.

Margheri, M.C., Ventura, S., KaštovskÝ, J. \& Komárek, J. (2008): The taxonomic validation of the cyanobacterial genus Halothece. - Phycologia 47: 477-486.

RIPPKA, R. \& COHEN-BAZIRE, G. (1983): The Cyanobacteriales: a legitimate order based on the type strain Cyanobacterium stanieri? - Ann. Microbiol. (Inst. Pasteur) 134B: 21-36.

Roussomoustakaki, M. \& Anagnostidis, K. (1991): Cyanothece halobia, a new planktic chroococcalean cyanophyte from hellenic heliothermal saltworks. Algological Studies 64: 71-95.

Stam, W.T. \& Stulp, B.K. (1988): New taxonomic methods: DNA/DNA hybridisation. - Methods Enzymol. 167: 125-132.

Turner, S., Huang, T.C. \& Chaw, S.M. (2001): Molecular phylogeny of nitrogen-fixing unicellular cyanobacteria. - Bot. Bull. Acad. 42: 81-186.

WaArd, A.D. \& Duyvesteyn, M. (1980): Are sequencespecific deoxyribonucleases value as taxonomic markers of cyanobacterial species? -Arch. Microbiol. 128: 241-247.

Wilmotte, A., Turner, S., van de Peer, Y. \& Pace, N.R. (1992.): Taxonomic study of marine oscillatoriacean strains (Cyanobacteria) with narrow trichomes. II. Nucleotide sequence analysis of the 16S ribosomal RNA. - J. Phycol. 28: 828-838.

(C) Czech Phycological Society

Received October 29, 2009

Accepted January 26, 2010 